\title{
MANAJEMEN LABA DAN PERUBAHAN TARIF PPH \\ UNDANG-UNDANG NO. 36 TAHUN 2008 \\ (Studi Empiris pada Perusahaan BUMN dan Non-BUMN di BEI Tahun 2007-2010 )
}

\author{
Sri Suranta* \\ Bandi \\ Eko Arief Sudaryono \\ Program Studi Akuntansi Fakultas Ekonomi dan Bisnis \\ Universitas Sebelas Maret Surakarta \\ *Srisuranta@yahoo.com
}

\begin{abstract}
Income Tax Act current in Indonesia is marked by the issuance of Law No. 36 of 2008. These laws regulate some fundamental changes in the calculation of corporate income tax for companies in Indonesia. One of the most fundamental changes is the change in the rate used in calculating the tax for the company, which was originally using progressive rates (maximum rate of $30 \%$ ) to $28 \%$ in 2009, and will be $25 \%$ in 2010.

This study is a descriptive study with a quantitative approach. Based on predefined criteria sample, then the total number of samples studied is 193 samples. The variables of study include the discretionary accrual earnings management use with Jones model are current asset changes, cash changes, changes in current liabilities, changes in short-term debt, and changes to the income tax paid. Methods of data collection with secondary data are obtained through documentation of ICMD years 2007-2010. Analysis use parametric statistical with $t$-test and the non-parametric with Wilcoxon test.

The results showed all the company showed indications of earnings management before and after the tax law No. 36 in 2008. State-owned companies showed no difference in earnings management prior to the year after adoption of Law No. 36 in 2008, meanwhile the non-SOE companies show indication of earnings management.
\end{abstract}

Keywords: The issuance of Law No. 36 of 2008, income tax, earnings management, discretionary current accruals.

\section{PENDAHULUAN}

Reformasi Undang-undang Pajak Penghasilan terkini di Indonesia ditandai dengan dikeluarkannya Undang-undang Nomor 36 Tahun 2008. Undang-undang ini mengatur beberapa perubahan mendasar dalam perhitungan pajak penghasilan badan bagi perusahaan di Indonesia. Salah satu perubahan yang paling mendasar adalah adanya perubahan tarif yang digunakan dalam menghitung pajak bagi perusahaan, yang semula menggunakan tarif progresif (tarif maksimal 30\%) menjadi $28 \%$ pada tahun 2009, dan akan menjadi $25 \%$ pada tahun 2010. Hal ini berarti, setelah berlakunya Undang-undang Nomor 36 Tahun 2008 ini, perusahaan akan membayar pajak yang lebih kecil untuk jumlah penghasilan sama dengan periode sebelumnya. Dengan diberlakukannya tarif pajak yang baru ini, perusahaan khususnya yang telah go public akan sangat diuntungkan karena tarif pajak efektif perusahaan akan menjadi lebih kecil. Jika manajer berupaya untuk memaksimalkan nilai perusahaan dengan meminimalkan beban pajak, maka perubahan tarif ini akan memberikan insentif bagi manajer untuk menurunkan laba perusahaan pada tahun sebelum diefektifkannya perubahan tarif pajak tersebut.

Tujuan penelitian ini adalah menunjukkan bukti empiris bahwa perusahaan non-keuangan (BUMN, non BUMN) yang terdaftar di BEI periode 2007-2010 melakukan manajemen laba 
pada sebelum dan sesudah penerapan UU. No 36 Tahun 2008.

\section{METODOLOGI PENELITIAN}

Populasi penelitian ini adalah perusahaan non-keuangan yang terdaftar di Bursa Efek Indonesia. Metode pengambilan sampel menggunakan pengambilan sampel bertujuan (purposive sampling). Total sampel yang digunakan dalam penelitian ini sebanyak 193 perusahaan non keuangan yang terdaftar di BEI selama periode 2007 sampai dengan periode 2010. Pengambilan sampel bertujuan dilakukan dengan mengambil sampel dari populasi berdasarkan suatu kriteria-kriteria terntentu (Jogiyanto:2010, 79). Kriteria-kriteria yang diambil antara lain:

1. Perusahaan non keuangan yang listing di Bursa Efek Indonesia sebelum reformasi UU No 36 Tahun 2008 diberlakukan.

2. Menerbitkan data laporan keuangan yang lengkap selama periode pengamatan 20072010. Pemilihan rentang waktu bertujuan agar penelitian dapat lebih menunjukkan hasil yang lebih signifikan dan lebih akurat dibandingkan penelitian sebelumnya yang hanya dua atau tiga tahun sesudah UU PPh Badan tahun 2008 dikeluarkan.

3. Perusahaan tidak melakukan merger dan atau akuisisi pada saat terjadinya reformasi UU PPh Badan No. 36 Tahun 2008.

Data mengenai laporan keuangan dan laporan tahunan perusahaan diperoleh dari internet situs di www.idx.com, Indonesian Capital Market Directory (ICMD) maupun dari situs web perusahaan non keuangan yang telah diaudit tahun 2007-2010 dan jurnal, makalah, buku dan situs internet yang mendukung dengan topik penelitian ini.

Manajemen laba diukur dengan menggunakan discretionary current accrual yang diajukan oleh Guenther (1994). Metode ini banyak digunakan oleh peneliti lain, antara lain seperti Balachandran et al. (2007), Roubi, et al. (1998) dan Yin dan Cheng (2004).

$$
C A C C_{i t} / T A_{i t-1}=\beta_{i}\left[\Delta S A L E S_{i t} / T A_{i t-1}\right]+\varepsilon_{i t}
$$

yaitu:

$$
\begin{array}{ll}
\mathrm{CACC}_{\mathrm{it}} & =\text { akrual } \\
T A_{i t-1} & =\text { total asset tahun sebelumnya } \\
\triangle S A L E S_{i t} & =\text { perubahan penjualan }
\end{array}
$$

Adapun penghitungan akrual adalah sebagai berikut:

\begin{tabular}{|c|c|}
\hline $\mathrm{CACC}_{\mathrm{it}}$ & $=$ akrual saat ini; \\
\hline$\Delta C A_{i t}$ & $=$ perubahan asset lancer \\
\hline$\Delta$ Cash $_{i t}$ & $=$ perubahan kas \\
\hline$\Delta C L_{i t}$ & $=$ perubahan kewajiban lancar \\
\hline$\Delta S T D_{i t}$ & $\begin{aligned}= & \text { perubahan hutang jangka } \\
& \text { pendek }\end{aligned}$ \\
\hline$\Delta I T P_{i t}$ & $\begin{aligned}= & \text { perubahan pajak penghasilan } \\
& \text { yang dibayarkan }\end{aligned}$ \\
\hline
\end{tabular}

$C A C C_{i t}=\left(\Delta C A_{i t}-\Delta C a s h_{i t}\right)-\left(\Delta C L_{i t}-\Delta S T D_{i t}-\Delta I T P_{i t}\right)$

yaitu:

Penghitungan discretionary current accrual adalah dengan mengurangkan current accrual dengan ekspektasi current accrual seperti berikut ini

$$
D C A_{i t}=C A C C_{i t} / T A_{i t-1}-E\left[C A C C_{i t} / T A_{i t-1}\right](3)
$$

Nilai ekspektasi diperoleh dari menjalankan persamaan 1 dengan menggunakan cross sectional model. Setelah diperoleh nilai koefisien beta maka persaman tersebut dijalankan lagi untuk memperoleh nilai ekspektasi.

Pengujian hipotesis dilakukan dengan menggunakan software SPSS, sedangkan teknis analisis menggunakan uji statistik deskriptif, uji asumsi klasik, uji beda T-test.

\section{HASIL DAN PEMBAHASAN Hasil Penelitian}

Populasi penelitian ini adalah seluruh perusahaan non keuangan yang terdaftar di BEI periode tahun 2007 sampai dengan 2010. Proses seleksi sampel berdasarkan kriteria yang telah ditetapkan, disajikan dalam Tabel 1. 
Tabel 1

Penetapan Sampel berdasarkan teknik Purposive

\begin{tabular}{clc}
\hline No & \multicolumn{1}{c}{ Kriteria } & Jumlah \\
\hline 1 & $\begin{array}{l}\text { Perusahaan BUMN yang terdaftar di BEI } \\
\text { periode 2007-2010 }\end{array}$ & 11 \\
2 & $\begin{array}{l}\text { Perusahaan non BUMN yang terdaftar di BEI } \\
\text { periode 2007-2010 }\end{array}$ & 7 \\
3 & $\begin{array}{l}\text { Perusahaan Keluarga yang terdaftar di BEI } \\
\text { periode 2007-2010 }\end{array}$ & 157 \\
4 & $\begin{array}{l}\text { Perusahaan non Keluarga yang terdaftar di BEI } \\
\text { periode 2007-2010 } \\
\text { Total sampel yang diteliti }\end{array}$ & 18 \\
& \multicolumn{1}{c}{193} \\
\hline
\end{tabular}

\section{Sumber: ICMD 2007-2010, data diolah}

Mean dari discretionary current accrual (DCA) tiap perusahaan non-keuangan masingmasing periode 2007 hingga 2010. Hasilnya sebagai berikut:

Tabel 2

Hasil Uji statistic deskriptive Total per tahun

\begin{tabular}{rrr}
\hline & Mean & Std.deviation \\
\hline 2007 & -.063993 & .2262563 \\
2008 & -.051799 & .3734948 \\
2009 & .122287 & .2631755 \\
2010 & .015103 & .2237091
\end{tabular}

\section{Sumber: data yang telah diolah SPSS, 2013}

Dari data di tabel 2, diketahui bahwa ratarata total total DCA 2007 didapatkan rata-rata sebesar $6,39 \%$. Hasil tersebut menunjukkan perusahaan non-keuangan pada tahun 2007 melakukan discretionary current accrual ratarata $6,39 \%$ dalam merespon perubahan UU No. 36 Tahun 2008.
Total DCA perusahaan non-keuangan tahun 2008 didapatkan rata-rata sebesar 5,17\%. Dari hasil tersebut menunjukkan perusahaan non-keuangan pada tahun 2008 melakukan discretionary current accrual rata-rata hanya $5,17 \%$ dalam merespon perubahan UU No.36 Tahun 2008.

Total DCA 2009 saat diterapkannya perubahan UU No. 36 Tahun 2008 untuk tarif $28 \%$ dan tambahan $5 \%$ didapatkan rata-rata sebesar $12,22 \%$. Hasil tersebut menunjukkan perusahaan non-keuangan pada tahun 2009 melakukan discretionary current accrual ratarata $12,22 \%$ dalam merespon perubahan UU No.36 Tahun 2008. Untuk total DCA 2010 saat diterapkannya perubahan tarif $25 \%$ dan tambahan $5 \%$ didapatkan rata-rata sebesar $1,51 \%$. Hasil tersebut menunjukkan yang merupakan hasil terendah diantara tahun yang lain.

Tabel 3

Hasil Uji statistic descriptive per-sektor

\begin{tabular}{ccccc}
\hline \multirow{2}{*}{ TAHUN } & \multicolumn{2}{c}{ BUMN } & \multicolumn{2}{c}{ NONBUMN } \\
\cline { 2 - 5 } & mean & $\begin{array}{c}\text { Std. } \\
\text { deviation }\end{array}$ & mean & $\begin{array}{c}\text { Std. } \\
\text { deviation }\end{array}$ \\
\hline 2007 & -.129180 & .1650299 & -.166043 & .2521770 \\
2008 & .040860 & .1949491 & -.162386 & .2560285 \\
2009 & .128890 & .2255830 & .206171 & .2483827 \\
2010 & .014470 & .0789481 & -.003114 & .0582069 \\
\hline
\end{tabular}

Sumber: data yang telah diolah SPSS, 2013 
Dari hasil di tabel 3, diketahui rata-rata DCA untuk perusahaan BUMN pada tahun 2007 memiliki rata-rata DCA terbesar, yaitu $12,91 \%$, sedangkan untuk tahun 2010 memiliki rata-rata DCA terkecil, yaitu $1,44 \%$. Total ratarata DCA tahun 2008 dan 2009 adalah 4,08\% dan $1,44 \%$. Pada perusahaan non BUMN pada tahun 2009 memiliki rata-rata DCA terbesar 20,61\%, sedangkan untuk tahun 2010 memiliki rata-rata DCA terkecil, yaitu $0,31 \%$. Total ratarata DCA tahun 2007 dan 2008 hampir sama yaitu $16,60 \%$ dan $16,23 \%$.

Hampir setiap perusahaan pada tahun 2009 memiliki rata-rata DCA terbesar, baik perusahaan BUMN, dan non BUMN. Ini menandakan adanya indikasi perusahaan melakukan manajemen laba pada saat perubahan tarif pajak sebesar $28 \%+5 \%$. Untuk tahun 2010, setiap perusahaan memiliki ratarata DCA terkecil. Dimungkinkan perusahaan setelah melakukan manajemen laba pada saat berlakunya perubahan tarif pajak, rata-rata tidak melakukan manajemen laba.

Berikut disajikan hasil pengujian normalitas data dengan uji KolmogorovSmirnov.

\section{Tabel 4}

Hasil Uji Normalitas Data Perusahaan BUMN

\begin{tabular}{rrr}
\hline BUMN & $2007-2008$ & $2009-2010$ \\
\hline $\begin{array}{r}\text { Asymp. Sig. } \\
\text { (2-tailed) }\end{array}$ & .977 & .139
\end{tabular}

\section{Sumber: data yang telah diolah SPSS, 2013}

Berdasarkan data tabel 4, data berdistribusi normal apabila tingkat signifikansinya menunjukkan nilai yang lebih besar dari 0,05. Dari pengujian diperoleh sig. KS pada BUMN 2007-2008 sebesar 0,977 dan BUMN 2009-2010 sebesar 0,139 yang lebih besar dari 0,05. Hal ini menunjukkan bahwa data accrual perusahaan BUMN sebelum dan sesudah penerapan tarif PPh UU No. 36 tahun 2008 berdistribusi normal.

Tabel 5

\section{Hasil Uji Normalitas Data Perusahaan non BUMN}

\begin{tabular}{rrr}
\hline NBUMN & 2007-2008 & 2009-2010 \\
\hline $\begin{array}{r}\text { Asymp. Sig. } \\
\text { (2-tailed) }\end{array}$ & .691 & .171
\end{tabular}

\section{Sumber: data yang telah diolah SPSS, 2013}

Berdasarkan data tabel 5, data berdistribusi normal apabila tingkat signifikansinya menunjukkan nilai yang lebih besar dari 0,05. Dari pengujian diperoleh sig. KS pada non BUMN 2007-2008 sebesar 0,691 yang lebih besar dari 0,05. Data accrual perusahaan non BUMN 2009-2010 diperoleh sig. K-S sebesar 0,171 yang lebih besar dari 0,05. Hal ini menunjukkan bahwa data accrual perusahaan non BUMN sebelum dan sesudah penerapan tarif $\mathrm{PPh}$ UU No. 36 tahun 2008 berdistribusi normal.

\section{Pengujian Hipotesis 1}

Pengujian hipotesis penelitian untuk mengetahui perbedaan diantara kedua variabel yaitu data perusahaan sebelum dan setelah penerapan penurunan tarif $\mathrm{PPh}$ dilakukan dengan uji t paired-sample test diperoleh hasil sebagai berikut:

\section{Tabel 6}

Hasil Uji Paired Sample Test Perusahaan

Periode 2007-2010

\begin{tabular}{cccc}
\hline & T & Sig & Kesimpulan \\
\hline DCA07_08 - DCA09_10 & -6.351 & .000 & Ho ditolak, Ha diterima
\end{tabular}

Sig. : probabilitas $<5 \%$

Sumber: data yang telah diolah SPSS, 2013 
Berdasarkan tabel di atas memperlihatkan nilai Sig. $t$ sebesar 0,000 lebih kecil dari 0,05. Dengan hasil tersebut dapat disimpulkan bahwa data accrual perusahaan sebelum dan setelah penerapan UU nomor 36 tahun 2008 adalah berbeda secara nyata. Dapat dikatakan bahwa ada perbedaan data accrual perusahaan sebelum dan setelah penerapan penurunan tarif $\mathrm{PPh}$.

\section{Pengujian Hipotesis 2}

Pengujian hipotesis penelitian untuk mengetahui perbedaan diantara kedua variabel yaitu data perusahaan BUMN periode 20072010 sebelum dan setelah penerapan UU nomor 36 tahun 2008 dilakukan dengan uji t pairedsample testdiperoleh hasil sebagai berikut:

Tabel 7

Hasil Uji Paired Sample Test Perusahaan BUMN Periode 2007-2010

\begin{tabular}{llll}
\hline & T & Sig. & Kesimpulan \\
\hline BUMN07_08 - BUMN09_10 & -1.672 & .111 & Ho diterima, Ha ditolak
\end{tabular}

Sig. : probabilitas $<5 \%$

Sumber: data yang telah diolah SPSS, 2013

Berdasarkan tabel di atas memperlihatkan nilai Sig. t sebesar 0,111 lebih besar dari 0,05. Dengan hasil tersebut dapat disimpulkan bahwa data accrual perusahaan BUMN periode sebelum dan setelah penerapan UU nomor 36 tahun 2008 adalah tidak berbeda secara nyata. Dapat dikatakan bahwa tidak ada perbedaan data accrual diantara perusahaan
BUMNsebelum dan setelah penerapan UU nomor 36 tahun 2008 .

Pengujian hipotesis penelitian untuk mengetahui perbedaan diantara kedua variabel yaitu data perusahaan non BUMN sebelum dan setelah penerapan UU nomor 36 tahun 2008 dilakukan dengan uji $\mathrm{t}$ paired-sample testdiperoleh hasil sebagai berikut:

Tabel 8

Hasil Uji Paired Sample Test Perusahaan Non BUMN Periode 2007-2010

\begin{tabular}{llll}
\hline & T & Sig. & Kesimpulan \\
\hline NBUMN07_08 - NBUMN09_10 & -2.752 & .016 & Ho ditolak, Ha diterima
\end{tabular}

Sig. : probabilitas $<5 \%$

Sumber: data yang telah diolah SPSS, 2013

Berdasarkan tabel di atas memperlihatkan nilai Sig. t sebesar 0,016 lebih kecil dari 0,05. Dengan hasil tersebut dapat disimpulkan bahwa data accrual perusahaan BUMN sebelum dan setelah penerapan UU nomor 36 tahun 2008 adalah berbeda secara nyata. Dapat dikatakan bahwa ada perbedaan data accrual diantara perusahaan BUMNsebelum dan setelah penerapan UU nomor 36 tahun 2008.

\section{Pengujian Hipotesis 1}

Hasil uji $\mathrm{t}$ dengan paired sample test menunjukan bahwa data accrual perusahaan sebelum dan setelah penerapan penurunan tarif PPh UU nomor 36 tahun 2008 adalah berbeda secara nyata. Berdasarkan hasil uji hipotesis 
yang berarti bahwa $\mathrm{H}_{1}$ yang menyatakan bahwa terdapat perbedaan manajemen laba pada perusahaan sebelum dan sesudah penerapan tarif PPh UU nomor 36 tahun 2008. Dapat dikatakan bahwa ada perbedaan data accrual diantara perusahaan sebelum dan sesudah penurunan tarif $\mathrm{PPh}$ badan.

Hasil ini bertentangan dengan penelitian Hidayati dan Zulaikha (2003), dan Suwardi (2011) yang hasilnya tidak direspon oleh Wajib Pajak untuk melakukan manajemen laba dengan motivasi untuk meminimumkan beban pajak penghasilan perusahaan. Selain itu, hasil penelitian ini mendukung penelitian Yulianti dan Christine (2010), Subagyo dan Octavia (2010), dan Wijaya dan Martani (2011).

\section{Pengujian Hipotesis 2}

Hasil uji $\mathrm{t}$ dengan paired sample test menunjukkan bahwa data accrual perusahaan BUMN sebelum dan setelah penerapan UU nomor 36 tahun 2008 adalah tidak berbeda secara nyata. Hal ini dibuktikan dengan nilai signifikan $0,111>0,05$; yang berarti bahwa $\mathrm{H}_{2 \mathrm{a}}$ menyatakan tidak terdapat perbedaan manajemen laba pada perusahaan BUMN yang terdaftar di Bursa Efek Indonesia pada periode 2007-2010 sebelum dan sesudah penerapan tarif PPh UU nomor 36 tahun 2008.

Hasil uji $\mathrm{t}$ dengan paired sample test menunjukkan bahwa data accrual perusahaan non BUMN periode 2007-2010 sebelum dan setelah penerapan UU nomor 36 tahun 2008 adalah berbeda secara nyata. Hal ini dibuktikan dengan nilai signifikan $0,016<0,05$; yang berarti $\mathrm{H}_{2 \mathrm{~b}}$ menyatakan bahwa ada perbedaan perbedaan perilaku manajemen laba terhadap perubahan UU No.36 Tahun 2008. Berdasarkan hasil tersebut dapat dikatakan bahwa perusahaan non BUMN melakukan manajemen laba pada sebelum dan sesudah penerapan tarif $\mathrm{PPh}$ Undang-undang nomor 36 tahun 2008.

Hasil penelitian ini bertentangan dengan penelitian Bingxuan Lin, et al (2012) menguji perilaku perusahaan BUMN di China dalam menghadapi insentif untuk meminimalkan pajak karena ada pemotongan tarif. Hasilnya menunjukan perusahaan dengan persentase lebih besar saham yang dimiliki oleh negara melakukan manajemen laba dengan tujuan untuk mengurangi beban pajak mereka. Adapun di Indonesia, perusahaan BUMN tidak melakukan manajemen laba, sedangkan non BUMN melakukan manajemen laba saat penerapan tarif PPh UU No. 36 tahun 2008.

\section{KESIMPULAN}

Berdasarkan hasil penelitian dan pembahasan dapat disimpulkan bahwa :

1. Hasil pengujian hipotesis pertama terdapat indikasi perbedaan manajemen laba terhadap perubahan tarif PPh UU No. 36 tahun 2008 .

2. Pengujian kedua bahwa perusahaan BUMN yang terdaftar di Bursa Efek Indonesia tidak ada perbedaan manajemen laba pada sebelum dan sesudah perubahan tarif $\mathrm{PPh}$ UU No. 36 tahun 2008, sedangkan perusahaan non BUMN terdapat indikasi perbedaan manajemen laba pada sebelum dan sesudah perubahan tarif PPh UU No. 36 tahun 2008.

\section{Keterbatasan dan Saran}

Hasil penelitian ini memberikan tambahan bukti empiris mengenai teori keagenan dan kontribusi pengujian ulang terhadap penelitian terdahulu, khususnya mengenai discretionary accrual pada manajemen laba perusahaan BUMN dan non BUMN. Beberapa keterbatasan dan saran yang diajukan dalam penelitian ini, yaitu:

1. Pemilihan sampel dalam penelitian ini hanya menggunakan perusahaan BUMN dan non BUMN. Penelitian selanjutnya diharapkan untuk menambah jumlah sampel dengan memperluas jenis perusahaan, serta memperpanjang periode pengamatan.

2. Penelitian ini hanya membandingkan periode sebelum dan sesudah perubahan tarif pajak no. 36 tahun 2008 dengan menggunakan discretionary current accrual sebagai pembandingnya. Penelitian selanjutnya agar dapat menambah faktorfaktor yang berpengaruh terhadap manajemen laba yang dimotivasi oleh pajak. 


\section{DAFTAR PUSTAKA}

Arifin, Z. 2003. Masalah Agensi dan Mekanisme Kontrol pada Perusahaan dengan Struktur Kepemilikan Terkonsentrasi yang Dikontrol Keluarga: Bukti dari Perusahaan Publik di Indonesia. Disertasi Pascasarjana FEUI.

Arum, Harjanti Puspa. 2012. Pengaruh Kesadaran Wajib Pajak, Pelayanan Fiskus, dan Sanksi Pajak Terhadap Kepatuhan Wajib Pajak Orang Pribadi yang melakukan Kegiatan Usaha dan Pekerjaan Bebas.

SkripsidariUniversitasDiponeggoro, Semarang.

Balachandran, B., Godfrey, J., Hanlon, D., \& $\mathrm{Tu}, \mathrm{H}$. 2007. Earnings Management in Response to the Corporate Tax Law Changes Evidence from Australia Artikel dipersentasikan pada AAFANZ Conference, Gold Coast, Queensland.

Bernard, B. 1975. The development of organization structure in the family firm. Journal of General Manajemen, Autumn, page 42-60. www.academia.edu. $\quad 17$ November 2013

Chen, Shuping, Xia Chen, dan Terry Shevlin. 2009. Are Family Firm More Tax Aggressive than Non-Family Firms? Journal of Financial Economics, Vol. 95, page 41-61.

Churchill, N. C., and Hatten, K. J. 1987. Nonmarket-based transfers of wealth and power: a research framework for family businesses. American Journal of Small Busi-ness, Vol. 11, No.3, page 51-64.fbr.sagepub.com. 8 Januari 2014.

Devina, Birgita S.P. 2010. KemampuanBebanPajakTangguhanda nBebanPajakKinidalamDeteksiManaje menLabapadasaat Seasoned Equity Offering.
SkripsidariUniversitasDiponegoro, Semarang.

Fama, Eugene F., and Michael C. Jensen. 1983. Agency Problem and residual Claims. Journal of Law and Economics, Vol.26, No. 2, page 327-349. www.edegan.com. 5 Januari 2014.

Ghozali, Imam. 2011. Aplikasi Analisis Multivariate dengan Program SPSS. Semarang:Badan Penerbit Universitas Diponegoro.

Guenther, David A. 1994. Earnings Management in Response to Corporate Tax Rate Changes: Evidence from the 1986 Tax Reform Act. The Accounting Review, Vol.69, No. 1, page 230-243.

Handler, W. C. 1989. Managing the Family Firm Succession Process; The NextGeneration FamilyMember's Experience. Unpublished doctoral dissertation, School of Management, Boston University. www.uk.sagepub.com.20Desember 2013.

Hidayati, Siti Munfiah dan Zulaikha. 2003. Analisis Perilaku Earning Management : Motivasi Minimalisasi Income Tax. Artikel yang dipresentasikan pada Simposium Nasional Akuntansi VI Surabaya.

Jiambalvo, J. 1996. Discussion of Causes and Consequences of Earnings Manipulation. Contemporary Accounting Research. Vol. 13. Spring, page 37-47.onlinelibrary.wiley.com. 8 November 2013.

Jogiyanto. 2010. MetodologiPenelitianBisnis: Salah KaprahdanPengalamanPengalaman. Yogyakarta: BPFE.

Jones, J. J. 1991. Earnings management during import relief investigations. Journal of Accounting Research, Vol.29, no.2, page 193-228. 
Ikatan Akuntan Indonesia. 2009.Pernyataan Standar Akuntansi Keuangan No. 1: Pengajian Laporan Keuangan. Jakarta: Dewan Standar Akuntansi Keuangan.

Lin, B., Lu, R., \& Zhang, T. 2012. Tax-Induced Earnings Management in Emerging Markets: Evidence from China. The Journal of the American Taxation Association, Vol. 34, No. 2, page 1944. doi: 10.2308/atax-10236.

Li, O. Z., and Cai, N. 2011. Capital market research in taxation: Do it in China! China Journal of Accounting Research, 4(1-2), 1-7. doi: http://dx.doi.org/10.1016/j.cjar.2011.05 .001

Jones, J. J. 1991. Earnings management during import relief investigations. Journal of Accounting Research, Vol.9, No.2, 193-228.

Ortax.

2010.

$I C W$

TagihKomitmenPresidenSoalPajakGru

p Bakrie. Tempointeraktif.com. 23 Januari 2014.

Maury, B. 2006.Family ownership and firm performance: Empirical evidence from Western European corporations. Journal of Corporate Finance 12, page $321-$

341.www.catedrafamiliar.ehu.es.3Janu ari 2014.

Maydew, Edward L. 1997. Tax -induced Earnings Management by Firms with Net Operating Losses. Journal of Accounting Research. Spring, page 8396.

Miller, Eric J. dan A.K. Rice. 1967. Task and Sentient Systems and Their Boundary Controls. London :Tavistock Publications.

www.moderntimesworkplace.com.310 ktober 2013.
Prasetyo, R.B. 2008. Ketimpangan dan Pengaruh terhadapPembangunan Ekonomi. Skripsi Sarjana Ekonomi, IPB, Bogor.

Roubi, R. R., \& Richardson, A. W. 1998. Managing discretionary accruals in response to reductions in corporate tax rates in Canada, Malaysia and Singapore. The International Journal of Accounting, Vol.33, no.4, page 455467. http://dx.doi.org/.12 Desember 2013.

Scholes, M.S., G.P. Wilson and M.A. Wolfson. 1992. Firms' Responses to Anticipated Reduction in Tax Rates: The Tax Reform Act of 1986. Journal of Accounting Research, page 161185.aajournals.org. 12 Desember 2013.

Scott, R. William. 2000. Financial Accounting Theory. Second Edition, Prentice Hall Canada Iinc., Scarborough, Ontario, Canada.eprints.undip.ac.id/18294/2/Mu khlasin.pdf. 12 Desember 2013.

Subagio dan Oktavia. 2010. Manajemen Laba sebagai Respon atas Perubahan Tarif Pajak Penghasilan Badan di Indonesia. Artikel yang dipresentasikan pada Simposium Nasional Akuntansi XIII Purwokerto.

Susanto, A.B., Wijarnako, Himawan., Susanto, Particia., \& Mertosono, Suwahjuhadi.2007. The Jakarta Consulting Group on family business. Jakarta: The Jakarta Consulting Group.

Suwardi, E. 2011. Income Tax Rate and Earnings Management of Firms Listed on the Indonesian Stock Exchange. Artikel yang dipersentasikan pada International Business Conference ke 15, Sydney, Australia.

Undang-Undang Nomor 19 Tahun 2003 Tentang Badan Usaha Milik Negara. 
Undang-Undang Nomor 36 Tahun 2008 Tentang Pajak Penghasilan.

Wijaya, Maxson dan Dwi Martani. 2011. Praktik Manajemen Laba Perusahaan dalam Menanggapi Penurunan Tarif Pajak sesuai UU no. 36 Tahun 2008. Artikel yang dipresentasikan pada Simposium Nasional Akuntansi XIV Aceh.

Wiryandari, Santi Aryn dan Yulianti. 2008. Hubungan Perbedaan Laba Akuntansi \& Laba Pajak dengan Perilaku Manajemen Laba dan Persistensi Laba. Simposium Nasional Akuntansi IX, Padang.

Wisnumurti, Andhika. 2010. AnalisisPenegaruh Corporate Governance TerhadapHubunganAsimetriInformasid enganPraktikManajemenLaba.

SkripsiJurusanAkuntansi FE. UniversitasDipnegoro, Semarang.

Yin, Q. J., and Cheng, C. S. A. 2004. Earnings Management of Profit Firms and Loss Firms in Response to Tax Rate Reductions. Review of Accounting \& Finance, Vol.3, no.1, page 67-92.
Yulianti. 2005. Kemampuan Beban Pajak Tangguhan dalam Mendeteksi Manajemen Laba. Jurnal Akuntansi dan Keuangan Indonesia, Vol.2, No.1, page 107-129. accounting.fe.ui.ac.id. 23 Desember 2013.

dan Christine.2010. Pengaruh Penurunan Pajak dalam UndangUandang Pajak Penghasilan Tahun 2008 Terhadap Kebijakan Penyusunan Laporan Keuangan.Artikel yang dipresentasikan di Tax Administration Conference,

Sydney.sna.akuntansi.unikal.ac.id/mak alah/087-PPJK-18.pdf. 06 Januari 2014.

Yuniasih, Ni Wayan, N.K Rasmini, dan Made G. Wirakusuma. 2012. PengaruhPajakdan Tunneling Incentive padaKeputusan Transfer Pricing Perusahaan Manufaktur yang Listing di Bursa Efek Indonesia.SimposiumNasionalAkuntan si VX, Banjarmasin. 